\title{
Palaeoenvironmental reconstructions: a tribute to the career of Jef Vandenberghe (editorial)
}

\section{Kasse ${ }^{\star} \&$ H. Renssen}

Cluster Earth \& Climate, Faculty of Earth and Life Sciences, Vrije Universiteit Amsterdam, De Boelelaan 1081, 1081 HV Amsterdam, the Netherlands.

* Corresponding author. Email: c.kasse@vu.nl.

Professor Jef Vandenberghe retired on the $1^{\text {st }}$ of March 2011 after a long-lasting career at the Vrije Universiteit Amsterdam. He played a very important organisational and scientific role at our Faculty of Earth and Life Sciences and as a tribute to his career we organised a symposium for him entitled: 'Palaeoenvironmental reconstructions - fluvial, eolian, periglacial - Evolution of ideas and approaches in the past 35 years'. The symposium on $1^{\text {st }}$ April 2011 was well-attended, and colleagues, friends and former PhDstudents filled this day with scientific presentations. To further highlight the scientific achievements of professor Vandenberghe, it was also decided to publish a special issue in the Netherlands Journal of Geosciences. As guest editors, we invited the participants of the symposium and other colleagues to contribute to this special issue. Because of the many contributions we received in the past year, a double issue has been produced. The content of this issue reflects the research interests of professor Vandenberghe over the last decades, focussing on the reconstruction of Quaternary sedimentary environments (fluvial: brooks and rivers; aeolian: coversands and loess), climate change (permafrost and periglacial structures) and modelling. The papers in this special issue have been arranged according to these themes.

Vandenberghe started his career at Leuven University where he graduated in 1973 on the Geomorphology of the Zuiderkempen region in Flanders, Belgium (Vandenberghe, 1977). All the research elements and proxies used in his later work were already present then: morphology, stratigraphy, grain-size analyses, vegetation reconstruction, periglacial features (Vandenberghe, this issue). In many of his studies radiocarbon dating has provided the time control to reconstruct the evolution of landscapes (Van der Plicht, this issue).

In 1976 he started his career at the Vrije Universiteit. Fluvial research on river behaviour in relation to climate and vegetation change started on brooks (e.g. the Mark) in the southern Netherlands and northern Belgium (Vandenberghe et al., 1984). Later this research on climate and man-driven fluvial system change expanded to larger river systems like the Maas in the Netherlands (Busschers et al., 2007; De Moor et al., 2008), the Warta in Poland (Vandenberghe et al., 1994), the Tisza in Hungary (Kasse et al., 2010) and the Tagus in Portugal (Vis et al., 2008). Detailed case studies continue to enlarge our knowledge of fluvial systems and forcing factors at various time scales ranging from the Late Pleistocene (Janssens et al., this issue; French \& Demitroff, this issue), Middle Pleistocene (Gibbard et al., this issue) to the Quaternary (Gabris et al., this issue) and even to the Archaean (Van Loon et al., this issue).

In addition to fluvial case studies, Vandenberghe has constructed conceptual models of river behaviour over glacial-interglacial climatic cycles. Especially the importance of the short-lasting climatic transitions on channel pattern and incision-aggradation cycles has been a long-lasting interest (Vandenberghe, 1995, 2003, 2008). The studies by Bridgland \& Westaway (this issue), Demoulin et al. (this issue) of the Ardennes and Harmand and Cordier (this issue) of the Moselle catchment contribute to the understanding of the interplay of uplift, knick-point migration, climate cyclicity and terrace formation.

Besides fluvial studies, Vandenberghe's career is characterised by the study of aeolian sediments and environments in relation to climate change. Starting on sandy aeolian coversand deposits in the Netherlands and Belgium, and their relation to climate change during the Late Weichselian (Vandenberghe, 1991), his focus expanded rapidly to silty aeolian sediments in the famous archaeological site of Belvédère in the southern Netherlands (Vandenberghe et al., 1993). Meijs et al. (this issue) presents the state-of-the-art Middle and Late Pleistocene loess stratigraphy, correlation with the marine isotope record and latest archaeological finds in the Dutch-Belgian border region. 
In the 90's Vandenberghe was one of the first to start research on the long loess records in China, to establish a grain-size based chronology (Vandenberghe et al., 1997), using the technical improvements of grain-size analysis by laser diffraction (Konert \& Vandenberghe, 1997). Grain-size analysis has proven to be a powerful tool in the reconstruction of depositional changes in lacustrine (Vriend et al., this issue) and aeolian environments (Prins et al., 2007). The research on loess sequences has expanded over Asia and Europe in order to reconstruct atmospheric circulation patterns at an almost northern hemisphere scale (Vandenberghe et al., 2006; Bokhorst et al., 2011). The contributions by Varga et al. (this issue), Markovic et al. (this issue) and Lu et al. (this issue) demonstrate the scientific importance of loess records as archives of climate change.

The study of fossil periglacial features, often encountered in fluvial and aeolian successions, has been another long-lasting research topic of Vandenberghe. He reported on their cryostratigraphic position (Vandenberghe, 1985), genesis (Vandenberghe, 2006) and relation to climate and climate change in several papers, not only dealing with western and central Europe (Vandenberghe, 1992), but also in Asia (Vandenberghe et al., 2004). Czudek (this issue) and Van Loon et al. (this issue) demonstrate the importance of permafrost and periglacial processes on landscape evolution in Central Europe during the Quaternary.

Despite the fact that Vandenberghe's main contributions are related to the study of the geological archives, he acknowledged the importance of modelling as a tool in understanding earth system changes. Verstraeten (this issue) reviews the evolution of combining field and modelling approaches. Climate and fluvial modelling have become more important in Vandenberghe's research group in order to better understand the effect of different parameters and forcing factors in landscape evolution (Bogaart et al., 2003; Renssen et al., 2007; Ward et al., 2009; Vandenberghe et al., 2012; Keesstra et al., this issue).

More recently, Vandenberghe has stressed the importance of earth sciences for society. He has encouraged and facilitated the development of the Bachelor educational track Earth and Economics at the Vrije Universiteit. Vermaat and Bokhorst (this issue), deal with the opportunities of the integration of Earth Sciences and Economics. In the last decades more and more earth scientist are employed in the field of geoarcheology. As a consequence of the Valetta treaty the number of archeological excavations has strongly increased and the importance of earth-scientific knowledge in landscape reconstruction related to human occupation is more and more acknowledged (Isarin \& Aalbersberg, this issue).

We hope that Jef Vandenberghe will continue to contribute to earth sciences and we wish him the best in the coming years.

\section{References}

Bogaart, P.W., Van Balen, R.T., Kasse, C. \& Vandenberghe, J., 2003. Processbased modelling of fluvial system response to rapid climate change II. Application to the river Maas (the Netherlands) during the Last GlacialInterglacial Transition. Quaternary Science Reviews 22: 2097-2110.

Bokhorst, M.P., Vandenberghe, J., Sümegi, P., Lanczont, M., Gerasimenko, N.P., Matviishina, Z.N., Markovic, S.B. \& Frechen, M., 2011. Atmospheric circulation patterns in central and eastern Europe during the Weichselian Pleniglacial inferred from loess grain-size records. Quaternary International 234: $62-74$.

Bridgland, D. \& Westaway, R., 2012. The use of fluvial archives in reconstructing landscape evolution: the value of sedimentary and morphostratigraphical evidence. Netherlands Journal of Geosciences 1/2: 5-24, this issue.

Busschers, F.S., Kasse, C., Van Balen, R.T., Vandenberghe, J., Cohen, K.M., Weerts, H.J.T., Wallinga, J. Johns, C., Cleveringa, P. \& Bunnik, F.P.M., 2007. Late Pleistocene evolution of the Rhine-Meuse system in the Southern North Sea basin: imprints of climate change, sea-level oscillation and glacioisostacy. Quaternary Science Reviews 26: 3216-3248.

Czudek, T., 2012. Soft rock pediments in South Moravia, Czech Republic. Netherlands Journal of Geosciences 1/2: 215-222, this issue.

De Moor, J.J.W., Kasse, C., Van Balen, R., Vandenberghe, J. \& Wallinga, J., 2008. Human and climate impact on catchment development during the Holocene Geul River, the Netherlands. Geomorphology 98: 316-339.
Demoulin, A., Beckers, A., Rixhon, G., Braucher, R., Bourlès, D. \& Siame, L., 2012. Valley downcutting in the Ardennes (W Europe): Interplay between tectonically triggered regressive erosion and climatic cyclicity. Netherlands Journal of Geosciences 1/2: 79-90, this issue.

French, H. \& Demitroff, M., 2012. Late Pleistocene paleohydrography, eolian activity and frozen ground, New Jersey Pine Barrens, Eastern USA. Netherlands Journal of Geosciences 1/2: 25-35, this issue.

Gábris, G., Horváth, E., Novothny, A. \& Ruszkiczay-Rüdiger, Z., 2012. Fluvial and aeolian landscape evolution in Hungary - results of the last 20 years research. Netherlands Journal of Geosciences 1/2: 111-128, this issue.

Gibbard, P.L., Boreham, S., West, R.G. \& Rolfe, C., 2012. Late Middle Pleistocene glaciofluvial sedimentation in western Norfolk, England. Netherlands Journal of Geosciences 1/2: 63-78, this issue.

Harmand, D. \& Cordier, S., 2012. The Pleistocene terrace staircases of the present and past rivers downstream from the Vosges Massif (Meuse and Moselle catchments). Netherlands Journal of Geosciences 1/2: 91-109, this issue.

Isarin, $\boldsymbol{R}$. \& Aalbersberg, G., 2012. The role of earth sciences in Dutch archaeology. Netherlands Journal of Geosciences 1/2: 279-283, this issue.

Janssens, M., Kasse, C., Bohncke, S.J.P., Greaves, H., Cohen, K.M., Wallinga, J. \& Hoek, W.Z., 2012. Climate-driven fluvial development and valley abandonment at the last glacial-interglacial transition (Oude IJssel-Rhine, Germany). Netherlands Journal of Geosciences 1/2: 37-62, this issue.

Kasse, C., Bohncke, S.J.P. Vandenberghe, J. \& Gábris G., 2010 Fluvial style changes during the last glacial-interglacial transition in the middle Tisza valley (Hungary). Proceedings Geologists' Association 121: 180-194. 
Keesstra, S.D., Kondrlova, E., Czajka, A., Seeger, M. \& Maroulis, J., 2012. Assessing riparian zone impacts on water and sediment movement: a new approach. Netherlands Journal of Geosciences 1/2: 245-255, this issue.

Konert, M. \& Vandenberghe, J., 1997. Comparison of laser grain-size analysis with pipette and sieve analysis: a solution for the underestimation of the clay fraction. Sedimentology 44: 523-535.

Lu, H., Wang, X., Wang, X., Sun, X., Yi, S., Zhou, Y., Liu, Q., Swinehart, J. \& Vandenberghe, J., 2012. Palaeoclimatic changes in northeastern QinghaiTibetan Plateau revealed by magnetostratigraphy and magnetic susceptibility analysis of thick loess deposits. Netherlands Journal of Geosciences 1/2: 189-198, this issue.

Marković, S.B., Hambach, U., Stevens, T., Jovanović, M., O'Hara-Dhand, K., Basarin, B., Lu, H., Smalley, I., Buggle, B., Zech, M., Svirčev, Z., Sümegi, P., Milojković, N. \& Zöller, L., 2012. Loess in Vojvodina region (Northern Serbia): an essential link between European and Asian Pleistocene environments. Netherlands Journal of Geosciences 1/2: 173-188, this issue.

Meijs, E.P.M., Van Peer, Ph. \& De Warrimont, J.P.L.M.N., 2012. Geomorphologic context and proposed chronostratigraphic position of Lower Palaeolithic artefacts from the 0p de Schans pit near Kesselt (Belgium) to the west of Maastricht. Netherlands Journal of Geosciences 1/2: 137-157, this issue.

Prins, M.A., Vriend, M., Nugteren, G., Vandenberghe, J., Lu, H., Zheng, H. \& Weltje, G.J., 2007. Late Quaternary aeolian dust flux variability on the Chinese Loess Plateau: Inferences from unmixing of loess grain-size records. Quaternary Science Reviews 26: 230-242.

Renssen, H., Kasse, C., Vandenberghe, J. \& Lorenz, S.J., 2007. Weichselian Late Pleniglacial surface winds over Northwest and Central Europe: a model-data comparison. Journal of Quaternary Science 22: 281-293.

Vandenberghe, J., 1977. Geomorfologie van de Zuiderkempen. Verhandelingen van de Koninklijke Academie voor Wetenschappen, Letteren en Schone Kunsten van Belgie, Jrg XXXIX, Nr. 140, 166 pp.

Vandenberghe, J., 1985. Paleoenvironment and stratigraphy during the Last Glacial in the Belgian-Dutch border region. Quaternary Research 24: 23-38.

Vandenberghe, J., 1991. Changing conditions of aeolian sand deposition during the last deglaciation period. Zeitschrift für Geomorphologie Neue Folge, Supplement-Band 90: 193-207

Vandenberghe, J., 1992. Periglacial phenomena and Pleistocene environmental conditions in the Netherlands - an overview. Permafrost and Periglacial Processes 3: 363-374.

Vandenberghe J., 1995. Timescales, climate and river development. Quaternary Science Reviews 14: 631-638.

Vandenberghe J., 2003. Climate forcing of fluvial system development: an evolution of ideas. Quaternary Science Reviews 22: 2053-2060.

Vandenberghe, J., 2006. Cryoturbation structures. In: Elias, S.A. (ed.): Encyclopedia of Quaternary Science. Elsevier (Amsterdam): 2147-2153.

Vandenberghe J., 2008. The fluvial cycle at cold-warm-cold transitions in lowland regions: A refinement of theory. Geomorphology 98: 275-284.

Vandenberghe, J., 2012. Multi-proxy analysis: a reflection on essence and potential pitfalls. Netherlands Journal of Geosciences 1/2: 263-269, this issue.

Vandenberghe, J., Paris, P., Kasse, C., Gouman, M. \& Beyens, L., 1984. Paleomorphological and botanical evolution of small lowland valleys - A case study of the Mark valley in northern Belgium. Catena 11: 229-238.
Vandenberghe, J., Roebroeks, W. \& Van Kolfschoten, T. (eds), 1993. MaastrichtBelvédère: stratigraphy, palaeoenvironment and archaeology of the Middle and Late Pleistocene deposits Part II. Mededelingen Rijks Geologische Dienst 47, $91 \mathrm{pp}$.

Vandenberghe, J., Kasse, C., Bohncke, S. \& Kozarski, S., 1994. Climate-related river activity at the Weichselian-Holocene transition: a comparative study of the Warta and Maas rivers. Terra Nova 6: 476-485.

Vandenberghe, J., An Z., Nugteren, G., Lu H. \& Van Huissteden, J., 1997. New absolute time scale for the Quaternary climate in the Chinese loess region by grain-size analysis. Geology 25-1: 35-38.

Vandenberghe, J., Cui, Z.J., Zhao, L. \& Zhang, W., 2004. Thermal contraction crack networks as evidence for Late-Pleistocene permafrost in Inner Mongolia. Permafrost and Periglacial Processes 15: 21-29.

Vandenberghe, J., Renssen, H., van Huissteden, K., Nugteren, G., Konert, M., Lu, H., Dodonov, A. \& Buylaert, J.-P., 2006. Penetration of Atlantic westerly winds into Central and East Asia. Quaternary Science Reviews 25: 2380-2389.

Vandenberghe, J., Renssen, H., Roche, D. M., Goosse, H., Velichko, A.A., Gorbunov, A. \& Levavasseur, G., 2012. Eurasian permafrost instability constrained by reduced sea-ice cover. Quaternary Science Reviews 34: 16-23.

Van der Plicht, H., 2012. Borderline Radiocarbon. Netherlands Journal of Geosciences 1/2: 257-261, this issue.

Van Loon, A.J., Bazkiewicz, M. \& Degórski, M., 2012. The role of permafrost in shaping the Late Glacial relief of northern Poland. Netherlands Journal of Geosciences 1/2: 223-231, this issue.

Van Loon, A.J., Mazumder, R. \& De, S., 2012. Unravelling the depositional environment of the Archaean Rajkharsawan conglomerate (Jharkhand, eastern India). Netherlands Journal of Geosciences 1/2: 129-135, this issue.

Varga, G., Kovács, J. \& Újvári, G., 2012. Late Pleistocene variations of the background aeolian dust concentration in the Carpathian Basin: an estimate using decomposition of grain-size distribution curves of loess deposits. Netherlands Journal of Geosciences 1/2: 159-171, this issue.

Vermaat, J.E. \& Bokhorst, M. , 2012. Earth Sciences and Economics, a productive and dynamic interface awaiting exploration. Netherlands Journal of Geosciences 1/2: 271-277, this issue.

Verstraeten, G., 2012. Combining quantitative field and modelling approaches towards understanding landscape dynamics: an evolution of ideas spanning Jef Vandenberghe's research career. Netherlands Journal of Geosciences 1/2: 233-244, this issue.

Vriend, M., Groot, M.H.M., Hooghiemstra, H., Bogotá-Angel, R.G. \& Berrio, J.C., 2012. Changing depositional environments in the Colombian Fúquene Basin at submillennial time-scales during 284-27 ka from unmixed grain-size distributions and aquatic pollen. Netherlands Journal of Geosciences 1/2: 199-214, this issue.

Ward, P.J., Van Balen, R.T., Verstraeten, G., Renssen, H. \& Vandenberghe, J., 2009. The impact of land use and climate change on late Holocene and future suspended sediment yield of the Meuse catchment. Geomorphology 103: 389-400. 